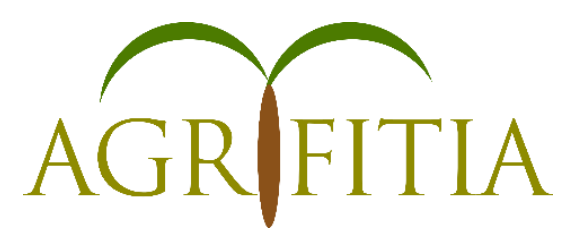

Journal Agrifitia. Vol. 1, No. 2, September 2021

Journal home page: https://jurnal.instiperjogja.ac.id/index.php/AFT

\title{
ANALISIS USAHATANI DAN PROFITABILITAS TANAMAN KOPI DI KECAMATAN GANGGA, KABUPATEN LOMBOK UTARA, NUSA TENGGARA BARAT
}

\author{
Gregorius Indra Umbu Geti ${ }^{1}$, Arum Ambarsari ${ }^{1}$, Amallia Ferhat ${ }^{1}$ \\ ${ }^{1}$ Jurusan Ekonomi Pertanian, Fakultas Pertanian, INSTIPER Yogyakarta
}

\begin{abstract}
ABSTRAK
Penelitian ini bertujuan untuk : 1) Mengetahui pendapatan usahatani kopi di Kecamaatan Gangga; 2) Mengetahui kelayakan usahatani kopi di Kecamatan Gangga;3) Mengetahui tingkat profitabilitas usahatani di Kecamatan Gangga. Metode analisis yang digunakan dalam melakukan penelitian ini adalah metode deskriptif. Penentuan lokasi dilakukan dengan cara purposive sampling dengan metode penentuan sampel snowball sampling sebanyak 30 responden petani kopi. Analisis yang digunakan untuk menjawab tujuan yaitu dengan menggunakan rumus pendapatan total penerimaan dikurangi total biaya, analisis $R / C$ ratio dan analisis profitabilitas untuk mengetahui tingkat keuntungan yang didapat usahatani kopi di Kecamatan Gangga. Dari hasil penelitian diketahui bahwa usahatani kopi di Kecamatan Gangga rata-rata pendapatan yang diperoleh sebesar Rp.12.581.046 per tahunnya dan analisis $\mathrm{R} / \mathrm{C}$ ratio yang didapat sebesar 3,9 yang membuktikan bahwa usahatani kopi layak untuk dijalankan. Untuk tingkat profitablitas yang diperoleh usahatani kopi sebesar $295 \%$ hal ini membuktikan bahwa profitabilitas yang ada didapat usahatani di Kecamatan Gangga, Kabupaten Lombok Utara, Nusa Tenggara Barat dua kali lipat dari pada biaya produksi yang dikeluarkan.
\end{abstract}

Kata kunci : Usahatani, Pendapatan, Profitabilitas, Kopi 


\section{PENDAHULUAN}

Kopi merupakan salah satu hasil komoditi perkebunan yang memiliki nilai ekonomis yang cukup tinggi di antara tanaman perkebunan lainnya dan berperan penting sebagai sumber devisa negara. Keberhasilan agribisnis kopi membutuhkan dukungan semua pihak yang terkait dalam proses produksi kopi pengolahan dan pemasaran komoditas kopi. Upaya meningkatkan produktivitas dan mutu kopi terus dilakukan sehingga daya saing kopi di Indonesia dapat bersaing di pasar dunia (Rahardjo, 2012).

Peningkatan permintaan kopi dunia sangat mempengaruhi harga kopi saat ini, harga kopi sejak beberapa tahun terakhir cenderung mengalami penigkatan yang disebabkan oleh tingginya permintaan pasar dunia kepada kebutuhan kopi. volume dan nilai ekspor kopi Indonesia mengalami peningkatan yang bersifat fluktuasi (Pujiyanto,2016). Suatu usahatani dikatakan efektif jika petani dapat mengalokasikan sumberdaya yang mereka miliki secara baik, sedangkan dikatakan efisien jika pemanfaatan sumberdaya dapat menghasilkan keluaran yang melebihi masukan. Usahatani berdasarkan skala usahanya dapat dikelompokkan menjadi dua yaitu usahatani skala besar dan usahatani skala kecil. Usahatani pada skala luas atau besar umumnya memiliki modal besar, teknologi tinggi, manajemen modern atau bersifat komoersial, sedangkan usaha kecil umumnya bermodal kecil, teknologi tradisional dan bersifat ubsisten atau hanya untuk memenuhi kebutuhannya sendiri (Soekartawi 2006).

Pada saat ini di Nusa Tenggara Barat, terdapat beberapa daerah penghasil kopi. Salah satunya di Kabupaten Lombok Utara yang merupakan daerah penghasil kopi dengan luas lahan dan produksi yang besar.

Tabel 1. Luas Lahan dan Produksi Kopi Kabupaten Lombok Utara

\begin{tabular}{|c|c|c|c|}
\hline Kecamatan & $\begin{array}{c}\text { Total Luas Area } \\
(\mathrm{Ha}) \\
2020 \\
\end{array}$ & 2020 & $\begin{array}{c}\text { Rata-Rata Produksi } \\
(\mathrm{Kg} / \mathrm{Ha}) \\
2020 \\
\end{array}$ \\
\hline Pemenang & 199,2 & 60,8 & 301,7 \\
\hline Tanjung & 182,4 & 102,4 & 560,4 \\
\hline Gangga & 754 & 417,4 & 776,7 \\
\hline Kayangan & 114,7 & 56,2 & 353,1 \\
\hline Bayan & 200 & 99,8 & 531 \\
\hline
\end{tabular}

Sumber: BPS Kabupaten Lombok Utara, 2020

Dari tabel diatas maka dapat dijelaskan bahwa luas lahan dan produksi kopi yang ada di Kabupaten Lombok Utara sangat besar khususnya pada Kecamatan Gangga yang mempunyai luas area dan produksi kopi yang sangat besar dbandingkan dengan kecamatan lainnya. Hal ini membuktikan bahwa usahatani kopi yang terletak pada Kecamatan Gangga merupakan penghasilan yang besar dan berpengaruh terhadap pendapatan para petani kopi 
di Kecamatan Gangga, tingginya produksi kopi yang terletak di Kecamatan Gangga membuktikan bahwa rata- rata sumber penghasilan masyarakat menjadi besar.

\section{METODOLOGI PENELITIAN}

Metode penelitian yang akan digunakan ialah metode deskriptif, metode penelitian deskriptif, yaitu suatu metode yang meneliti untuk mendapatkan gambaran secara deskriptif dan aktual serta dapat menghasilkan data yang akan dikumpulkan kemudian dianalisa. Penentuan lokasi penelitian ini menggunakan metode penentuan lokasi secara sengaja (purposive). Pelaksanaan dilakukan di Bulan Februari hingga bulan Maret 2021.

Metode penelitian yang akan digunakan yaitu metode snowball sampling yaitu pengambilan sampling secara bergulir dari satu petani ke petani lainnya. Jumlah sampel yang akan diambil oleh peneliti sebanyak 30 petani di Desa Genggelang, Kecamatan Gangga, Nusa Tenggara Barat.

Jenis data yang digunakan dalam penelitian ini yaitu:

1. Data Primer

Data primer merupakan data penelitian yang diambil secara langsung dari responden atau sumber asli dengan wawancara secara khusus kepada petani di Desa Genggelang, Kecamatan Gangga, Kabupaten Lombok Utara, Nusa Tenggara Barat.

2. Data Sekunder

Data sekunder diperoleh dari instansi tertentu yang terkait serta berhubungan dengan petani kopi di Desa Genggelang, Kecamatan Gangga, Kabupaten Lombok Utara, Nusa Tenggara Barat.

Metode pengumpulan data yang akan digunakan dalam penelitian ini adalah:

1. Teknik Wawancara

Teknik wawancara yaitu teknik pengumpulan data yang dilakukan secara tatap muka dan dilakukan tanya jawab langsung antara peneliti dengan petani.

2. Teknik Kuesioner

Teknik Kuesioner yaitu teknik pengumpulan data dengan cara mengajukan pertanyaan secara tertulis kepada responden, yang kemudian diberikan kepada peneliti.

Konseptualisasi variabel dan pengukuran:

1. Petani kopi adalah petani yang menanam tanaman kopi di kebun miliknya sendiri.

2. Penerimaan usahatani adalah produksi kopi yang dihasilkan selama satu kali musim tanam dikali dengan harga yang diperoleh petani. Penerimaan usahatani dihitung dengan satuan rupiah ( $\mathrm{Rp} / \mathrm{Ha} / \mathrm{Tahun})$. 
3. Produksi kopi adalah jumlah produksi yang diperoleh dalam bentuk buah kopi dalam satu periode musim tanam $(\mathrm{Kg} / \mathrm{Ha} / \mathrm{Th})$.

4. Harga kopi adalah harga buah kopi yang sudah ditentukan dalam pasar yang dihitung dengan satuan kilogram $(\mathrm{Kg})$.

5. Biaya tetap merupakan biaya yang dikeluarkan oleh petani secara tetap seperti biaya tenaga kerja, sewa lahan dan pajak lahan yang dihitung pertahun dalam satuan rupiah ( $\mathrm{Rp} / \mathrm{Ha} / \mathrm{Th})$.

6. Biaya variabel merupakan biaya yang dikeluarkan dalam melakukan satu kali produksi tanaman seperti biaya pupuk, biaya obat-obatan dan lain-lain yang dinyatakan dalam rupiah $(\mathrm{Rp} / \mathrm{Ha} / \mathrm{Th})$.

7. Luas lahan merupakan jumlah luas areal lahan yang digunakan oleh petani untuk menanam tanaman kopi yang dinyatakan dalam satuan hektar ( $\mathrm{Ha})$.

8. Biaya pupuk merupakan biaya yang dikeluarkan oleh petani untuk membeli pupuk yang digunakan selama satu musim tanam yang dihitung dalam satuan rupiah per hektar per musim ( $\mathrm{Rp} / \mathrm{Ha} / \mathrm{Th})$.

9. Biaya obat-obatan merupakan biaya yang dikeluarkan oleh petani untuk membeli obatobatan seperti pestisida untuk digunakan selama periode musim tanam yang dihitung dalam satuan rupiah per hektar per musim $(\mathrm{Rp} / \mathrm{Ha} / \mathrm{Th})$.

10. Biaya tenaga kerja merupakan biaya yang dikeluarkan untuk upah tenaga kerja dalam kegiatan produksi dihitung dalam satuan hari kerja $(\mathrm{Rp} / \mathrm{Ha} / \mathrm{Th})$.

11. Pendapatan usaha tani adalah pendapatan yang diperoleh dari usaha tani kopi yang merupakan total produksi dikurangi dengan semua biaya produksi yang dikeluarkan petani dalam usaha tani yang dinyatakan dalam rupiah $(\mathrm{Rp} / \mathrm{Ha} / \mathrm{Th})$.

12. Keuntungan (Profitabilitas) adalah selisih antara penerimaan dengan seluruh biaya usahatani kopi termasuk tenaga kerja dalam keluarga dan bunga modal sendiri per usahatani. Keuntungan dihitung dengan satuan rupiah ( $\mathrm{Rp} / \mathrm{Ha} / \mathrm{Th})$.

Analisis data dan pembentukan model:

1. Biaya Produksi

Biaya produksi adalah biaya yang dikeluarkan oleh usahatani dalam satu musim tanam untuk keperluan usahataninya, untuk menghitung biaya total tersebut maka dapat dirumuskan sebagai berikut :

$$
\mathrm{TC}=\mathrm{TFC}-\mathrm{TVC}
$$

Keterangan:

TC : Total biaya

TFC : Total biaya tetap

TVC : Total biaya variable 


\section{Pendapatan}

Pendapatan usahatani terdiri dari penerimaan dan pendapatan, penerimaan merupakan hasil pemasukan yang diperoleh sebelum dikurangi total biaya yang dirumuskan sebagai berikut:

$$
\begin{aligned}
& \text { TR = Py. } Y \\
& \text { Pendapatan = TR }- \text { TC }
\end{aligned}
$$

Keterangan:

TR : Total penerimaan

Py : Harga per produk

Y : Jumlah produk

TC : Total Biaya

3. Analisis R/C Rasio

Analisis R/C Rasio (Revenue/Cost Ratio) digunakan untuk mengetahui kelayakan usahatani kopi yang dijalankan oleh petani dan dirumuskan seperti berikut:

$$
\frac{R}{C}=\frac{\mathrm{TR}}{\mathrm{TC}}
$$

Keterangan:

$\mathrm{R} / \mathrm{C}$ : Revenue Cost

TR : Total Revenue

TC : Total Cost

Kriteria untuk menentukan kelayakan usahatani ditentukan sebagai berikut:

a. Jika $R / C>1$, maka usahatani tersebut layak untuk dijalankan karena total penerimaan yang didapat lebih banyak dari total biaya yang dikeluarkan oleh usahatani tersebut.

b. Jika $\mathrm{R} / \mathrm{C}<1$, maka usahatani tersebut tidak layak untuk dijalankan karena total penerimaan yang didapat lebih kecil dari total biaya yang dikeluarkan.

c. Jika $R / C=1$, maka usahatani tersbut mengalami impas karena total penerimaan sama dengan total biaya.

4. Profitabilitas

Profitabilitas merupakan kemampuan sebuah perusahaan untuk memperoleh keuntungan dengan jangka waktu tertentu yang dapat dihitung dengan rumus berikut:

$$
\text { Profitabilitas }=\frac{\text { Pendapatan bersih }}{\text { biaya produksi }} \times 100 \%
$$




\section{HASIL DAN PEMBAHASAN}

\section{A. Identitas Responden}

Responden dalam penelitian ini adalah petani kopi yang terletak di Kecamatan Gangga, Kabupaten Lombok Utara, NTB. Identitas petani kopi dalam penelitian ini dalam mengetahui latar belakang petani mencakup usia, tingkat pendidikan, jumlah anggota keluarga dan luas lahan. Dalam penelitian ini jumlah responden diambil sebanyak 30 petani dengan identitas responden seperti berikut:

1. Usia

Tabel 2 Identitas Petani Kopi Kecamatan Gangga

\begin{tabular}{cccc}
\hline No & Usia & Jumlah (jiwa) & Persentase (\%) \\
\hline 1 & $20-29$ & 4 & 13,33 \\
2 & $30-39$ & 9 & 30 \\
3 & $40-49$ & 9 & 30 \\
4 & $50-59$ & 4 & 13,33 \\
5 & $60-69$ & 4 & 13,33 \\
& Jumlah & 30 & 100 \\
\hline \multicolumn{4}{r}{}
\end{tabular}

Sumber: Data Primer, 2021

Berdasarkan tabel 2 diatas maka dapat disimpulkan bahwa mayoritas usia petani kopi di Kecamatan Gangga ada pada rentang usia 30-39 tahun dan 40-49 tahun yaitu sebanyak 9 jiwa dengan persentase 30\%, Sedangkan usia petani kopi dengan rentang 20-29 tahun, 5059 tahun dan 60-69 tahun sama-sama sebanyak 4 jiwa dengan persentase $13.33 \%$. Usia sangat mempengaruhi tingkat kerja seorang petani, karena semakin petani ada dalam usia produktif maka semakin produktif dan meningkatkan produktivitas tanaman kopi petani tersebut dalam mengolah usahatani.

2. Tingkat Pendidikan

Tabel 3 Identitas petani berdasarkan tingkat Pendidikan Kecamatan Gangga

\begin{tabular}{cccc}
\hline No & Tingkat Pendidikan & Jumlah (jiwa) & Persentase (\%) \\
\hline 1 & SD & 11 & 36,67 \\
2 & SMP & 8 & 26,67 \\
3 & SMA & 10 & 33,33 \\
4 & S1 & 1 & 3,33 \\
& Jumlah & 30 & 100 \\
\hline
\end{tabular}

Sumber: Data Primer, 2021

Berdasarkan tabel 3 dapat disimpulkan bahwa jumlah tingkat Pendidikan petani kopi di kecamatan Gangga yang paling tinggi ada pada tingkat Sekolah Dasar (SD) sebanyak 11 jiwa dengan persentase $36,67 \%$. Sedangkan tingkat Pendidikan dengan jumlah yang paling rendah ada pada tingkat Perguruan Tinggi (S1) sebanyak 1 jiwa dengan persentase 3.33\%. Tingkat pendidikan petani kopi di Kecamatan Gangga cukup bagus dan tidak terlalu rendah 
hal ini sangat membantu untuk pengembangan usahatani kopi milik petani yang dipengaruhi oleh tingkat pendidikan.

3. Luas Lahan

Tabel 4. Identitas petani berdasaarkan luas lahan di kecamatan Gangga

\begin{tabular}{cccc}
\hline No & Luas Lahan (Ha) & Jumlah (jiwa) & Persentase (\%) \\
\hline 1 & $0,5-1,5$ & 18 & 60 \\
2 & $1,6-3$ & 11 & 36,67 \\
3 & $3,1-5$ & 1 & 3,33 \\
& Jumlah & 30 & 100 \\
\hline
\end{tabular}

Sumber: Data Primer, 2021

Berdasarkan tabel 4 dapat disimpulkan bahwa luas lahan petani kopi paling banyak ialah luas lahan 0,5-1,5 Ha sebanyak 18 jiwa dengan persentase $60 \%$. Sedangkan luas lahan petani paling kecil ialah luas lahan $>3 \mathrm{Ha}$ sebanyak 1 jiwa dengan persentase $3.33 \%$. untuk petani kopi dengan luas lahan 1,6-3 Ha mempunyai sebanyak 11 jiwa dengan persentase $36,67 \%$. Untuk rata-rata luas lahan petani yang terletak di Kecamatan Gangga ialah $1.6 \mathrm{Ha}$. Luas lahan juga sangat berpengaruh dalam peningkatan produktivitas tanaman kopi, karena semakin tinggi luas lahan maka semakin tinggi juga produktivitas yang didapatkan oleh petani.

\section{B. Budidaya Tanaman Kopi}

Budidaya tanaman kopi yang dilakukan petani di Kecamatan Gangga dalam merawat tanaman seperti memupuk, memangkas dan pengendalian OPT. Untuk kegiatan memupuk tanaman kopi dilakukan secara 2 kali dalam setahun, petani biasa menggunakan pupuk urea, pupuk organik dan NPK dengan pengaplikasian secara tugal. Dalam kegiatan memangkas juga dilakukan 2 kali dalam setahun yang biasanya dilakukan setelah panen dan 6 bulan setelahnya, serta dalam kegiatan pengendalian OPT (Organisme Pengganggu Tanaman) petani di Kecamatan Gangga rata-rata adalah petani organik jadi hanya beberapa petani saja yang menggunakan obat- obatan untuk mengendalikan OPT seperti Foradan, Alika dan Trikoderma. Untuk hama yang menyerang biasanya adalah penggerek batang, dan semut oleh karena itu untuk mengendalikan dilakukan dengan disemprot area yang terdampak oleh hama tersebut.

Kegiatan panen yang dilakukan oleh petani di Kecamatan Gangga biasanya dilakukan pada bulan Agustus - September dan petani melakukan panen dengan cara petik merah sehingga panen biasanya dilakukan sampai dengan 1 bulan lebih. Untuk kegiatan pasca panen rata-rata petani melakukan pengolahan kering karena alat yang terbatas dan menurut petani mudah untuk dilaksanakan dan petani menjual hasil panen secara gelondongan kepada pengepul.

\section{Penggunaan Sarana Produksi}

Penggunaan sarana produksi merupakan alat atau jasa yang digunakan petani dalam membantu mengelola usahatani kopi di Kecamatan Gangga ini beruna sarana produksi 
pupuk, obat-obatan dan tenaga kerja yang kemudian penggunaan pupuk digunakan sebagai berikut:

1. Pupuk

Tabel 5. Penggunaan sarana produksi pupuk dalam usahatani kopi di kecamatan Gangga

\begin{tabular}{ccc}
\hline Jenis Pupuk & UT (kg/th) & Ha (kg/th) \\
\hline Urea & 76,67 & 46,46 \\
Pupuk Organik & 1125 & 681,82 \\
NPK & 15 & 9,09 \\
\hline \multicolumn{3}{c}{ Sumber: Data Primer, 2021 }
\end{tabular}

Pada tabel 5, menunjukan bahwa penggunaan sarana produksi pupuk dalam usahatani kopi di Kecamatan Gangga dengan jenis pupuk urea sebesar 76,67 Kg/Th per usaha tani yang dijalankan dan untuk per hektar sebesar rata-rata penggunaan pupuk sebesar 46,46 $\mathrm{Kg} / \mathrm{Th}$, untuk jenis pupuk organik rata-rata penggunaannya per usahatani sebesar $1125 \mathrm{Kg} / \mathrm{Th}$ dan untuk penggunaan per hektar sebesar $681,82 \mathrm{Kg} / \mathrm{Th}$. Sedangkan untuk rata- rata penggunaan pupuk NPK per usahatani sebsar $15 \mathrm{Kg} / \mathrm{Th}$ dan untuk penggunaan per hektar sebesar 9,09Kg/Th. Para petani di Kecamatan Gangga pada umumnya lebih dominan menggunakan pupuk organik karena lebih murah dan tidak ada kandungan bahan kimia dalampupuk tersebut sehingga menjaga kualitas biji kopi.

2. Obat-obatan

Tabel 6. Rata-rata penggunaan obat-obatan dalam usahatani kopi di kecamatan Gangga

\begin{tabular}{ccc}
\hline Jenis Obat-Obatan & UT (Lt/Th) & Ha (Lt/Th) \\
\hline Foradan & 0,10 & 0,06 \\
Alika & 0,10 & 0,06 \\
Trikoderma & 0,83 & 0,51
\end{tabular}

Sumber: Data Primer, 2021

Pada tabel 6 menunjukan bahwa penggunaan obat-obatan dalam usahatani kopi di Kecamatan Gangga dengan jenis obat-obatan foradan yang digunakan per usahatani sebesar 0,10Lt/Th dan rata- rata penggunaan per hektar sebesar 0,06Lt/Th. Untuk jenis obat Alika penggunaan per usahatani sebesar $0,10 \mathrm{Kg} / \mathrm{Th}$ dan untuk penggunaan per hektar sebesar 0,06 Lt/Th. Sedangkan untuk jenis obat trikoderma penggunaannya per usahatani sebesar 0,83Lt/Th dan untuk penggunaan dalam per hektar sebesar 0,51Lt/Th. Petani di Kecamatan Gangga tidak terlalu menggunakan obat-obatan dalam perawatan tanaman kopi, hal ini disebabkan para petani sangat menghindari penggunaan bahan kimia untuk diaplikasikan pada tanaman. 


\section{Tenaga Kerja}

Tabel 7. Rata-rata penggunaan tenaga kerja dalam usahatani kopi di kecamatan Gangga

\begin{tabular}{lcccc}
\hline \multirow{2}{*}{ Uraian } & \multicolumn{2}{c}{ Dalam Keluarga (HK) } & \multicolumn{2}{c}{ Luar Keluarga (HK) } \\
& UT & Ha & UT & Ha \\
\hline Pemupukan & 5,44 & 3,30 & 3,90 & 2,36 \\
Pemangkasan & 4,57 & 2,77 & 3,05 & 1,85 \\
Pengendalian OPT & 1,93 & 1,17 & 2 & 1,21 \\
Pemanenan & 10,36 & 6,28 & 30,07 & 18,22 \\
\hline
\end{tabular}

Sumber: Data Primer, 2021

Pada tabel 7 menunjukan bahwa rata-rata penggunaan tenaga kerja dalam usahatani kopi di Kecamatan Gangga dalam penggunaan tenaga kerja dalam keluarga pada kegiatan pemupukan mempunyai harian kerja sebesar 5,44/UT/Th dan 3,30/Ha/Th. Pada kegiatan pemangkasan mempunyai harian kerja sebesar 4,57/UT/Th dan 2,77/Ha/Th. Pada kegiatan pengendalian OPT mempunya harian kerja sebesar 1,93/UT/Th dan 1,17/Ha/Th. Untuk kegiatan pemanenan mempunya harian kerja sebesar 10,36/UT/Th dan 6,28/Ha/Th. Sedangkan untuk tenaga kerja luar keluarga yang digunakan para petani dalam menjalankan usahatani pada kegiatan pemupukan tenaga kerja luar keluarga memiliki harian kerja sebesar $3,90 / \mathrm{UT} / \mathrm{Th}$ dan $2,36 / \mathrm{Ha} / \mathrm{Th}$. Pada kegiatan pemangkasan memiliki harian kerja sebesar 3,05/UT/Th dan 1,85/Ha/Th. Untuk kegiatan pengendalian OPT tenaga kerja luar keluarga mempunyai harian kerja sebesar 2/UT/Th dan 1,21/Ha/Th, dan untuk kegiatan pemanenan tenaga kerja luar keluarga memiliki harian kerja sebesar 30,07/UT/Th dan 18,22/Ha/Th.

\section{Analisis Biaya Usahatani Kopi}

Tabel 7. Rata-rata biaya operasional petani kopi di Kecamatan Gangga, Kabupaten Lombok Utara, NTB

\begin{tabular}{lcc}
\hline \multicolumn{1}{c}{ Jenis Biaya } & \multicolumn{2}{c}{ Rata-rata biaya (Rp/Th) } \\
& UT & Ha \\
\hline Biaya penyusutan & 400.677 & 242.484 \\
Biaya sewa lahan & 19.833 .333 & 12.020 .202 \\
Biaya pajak lahan & 104.833 & 63.535 \\
Biaya pupuk & 1.285 .833 & 779.293 \\
Biaya obat-obatan & 148.833 & 90.202 \\
Biaya tenaga kerja & 4.291 .840 & 2.601 .115 \\
\hline
\end{tabular}

Sumber: Data Primer, 2021

Pada tabel 7 dapat disimpulkan bahwa rata-rata biaya operasional petani kopi di Kecamatan Gangga, Kabupaten Lombok Utara, NTB dengan jenis biaya penyusutan alat sebesar Rp. 400.677/UT/Th dan Rp.242.484/Ha/Th. Rata-rata biaya pupuk petani kopi sebesar Rp.1.285.833/UT/Th dan Rp.779.293/Th/Ha, untuk rata-rata biaya obat-obatan sebesar Rp.148.833/UT/Th dan Rp90.202/HaTh, untuk rata-rata biaya tenaga kerja yang dikeluarkan sebesar Rp.4.291.840/UT/Th dan Rp.2.601.115/Ha/Th. 


\section{E. Pendapatan}

Tabel 8. Rata-rata pendapatan usahatani kopi di Kecamatan Gangga

\begin{tabular}{|c|c|c|c|}
\hline \multirow{2}{*}{ Uraian } & \multirow{2}{*}{ Satuan } & \multicolumn{2}{|c|}{ Jumlah } \\
\hline & & UT & $\mathrm{Ha}$ \\
\hline Produksi & $\mathrm{Kg}$ & 803 & 487 \\
\hline Harga Jual & $\mathrm{Rp} / \mathrm{Kg}$ & 21.000 & 21.000 \\
\hline Biaya & $\mathrm{Rp} / \mathrm{Th}$ & 4.270 .340 & 2.588 .085 \\
\hline Penerimaan & $\mathrm{Rp} / \mathrm{Th}$ & 16.851 .667 & 10.213 .131 \\
\hline Pendapatan & $\mathrm{Rp} / \mathrm{Th}$ & 12.581 .237 & 7.625 .046 \\
\hline
\end{tabular}

Pada tabel 8 maka dapat disimpulkan bahwa rata-rata pendapatan usahatani kopi di Kecamatan Gangga, Kabupaten Lombok Utara, NTB dengan produksi tanaman kopi sebesar $803 \mathrm{Kg} / \mathrm{Th}$ dan $487 \mathrm{Kg} / \mathrm{Ha}$ untuk Harga jual tanaman kopi dijual secara gelondongan seharga Rp.21.000/Kg. Untuk biaya produksi yang dikeluarkan per tahun sebesar Rp.4.270.340/Th/UT dan Rp.2.588.085/Th/Ha untuk penerimaan yang didapat dari usahatani kopi sebesar Rp.16.851.667/UT/Th dan Rp.10.213.131/Ha/Th sedangkan untuk pendapatan yang didapat usahatani kopi sebesar Rp.12.518.237/UT/Th dan Rp. 7.625.046/Ha/Th.

\section{F. Analisis R/C Ratio}

$$
\frac{\text { Rp. } 505.550 .000}{\text { Rp. } 133.155 .200}=3,9
$$

$\mathrm{R} / \mathrm{C}$ ratio yang diperoleh oleh usahatani kopi sebesar 3,9. Maka dapat disimpulkan bahwa usahatani kopi di Kecamatan Gangga, Kabupaten Lombok Utara, Nusa Tenggara Barat layak untuk dijalankan karena R/C > 1 yaitu total penerimaan yang diterima lebih besar dengan biaya yang dikeluarkan.

\section{G. Profitabilitas}

Profitabilitas yang didapat usahatani kopi di Kecamatan Gangga, Kabupaten Lombok Utara, Nusa Tenggara Barat dengan membagi pendapatan bersih dan total biaya produksi ialah sebagai berikut:

$$
\frac{\text { Rp. } 372.434 .800}{\text { Rp. } 133.155 .200} \times 100 \%
$$

Maka dapat disimpulkan bahwa profitabilitas yang didapat oleh usahatani kopi di Kecamatan Gangga, kabupaten Lombok Utara, Nusa Tenggara Barat sebesar 295\%. Berarti usahatani kopi yang dijalan oleh petani mendapatkan untung yang besar karena pendapatan bersih yang didapat lebih besar dari total biaya produksi yang dikeluarkan per tahun oleh petani kopi dan profitabilitas. 


\section{H. Pembahasan}

1. Pendapatan yang diperoleh oleh petani kopi di Kecamatan Gangga dalam pertahun cukup tinggi yaitu rata-rata sebesar Rp.12.581.327/UT/Th dan mendapat rata-rata pendapatan per bulan sebesar Rp.1.048.443/BIn/UT ini membuktikan bahwa petani kopi belum cukup sejahtera jika dibandingkan dengan UMR Kabupaten Lombok Utara yang sebesar Rp.4.200.479. jadi pendapatan petani kopi di Kecamatan Gangga hanya dapat membiayai untuk kehidupan sehari. Petani kopi akan lebih sejahterah apabila mengikuti anjuran budidaya dari dinas pertanian yaitu dengan cara menggunakan pupuk yang dianjurkan dan menanam varietas unggul agar produksi kopi meningkat dan memperluas lahan dengan cara melakukan pola tanam yang dipatenkan agar dapat meningkatkan rata-rata pendapatan yang ada sebelumnya.

2. Kelayakan usahatani di Kecamatan Gangga dikatan sangat layak karena R/C ratio yang diperoleh oleh usahatani sebesar 3,9 yang berarti $\mathrm{R} / \mathrm{C}$ ratio $>1$, maka dapat dikatatakan bahwa usahatani kopi di Kecamatan Gangga sangat layak untuk dijalankan karena total penerimaan yang didapatkan lebih tinggi daripada biaya yang dikeluarkan oleh usahatani kopi di Kecamatan Gangga dan apabila usahatani kopi dapat dijalan secara tekun maka ada kemungkinan nilai $\mathrm{R} / \mathrm{C}$ ratio yang ada akan dapat ditingkatkan dan dapat mensejahterakan petani.

3. Profitabilitas usahatani kopi di Kecamatan Gangga mendapat nilai sebesar $295 \%$ yang berarti nilai profit yang didapatkan oleh petani kopi 2 kali lebih besar dari profit yang ada serta dapat disimpulkan bahwa rata-rata usahatani kopi yang terletak di Kecamatan Gangga mendapatkan untung 2 kali lipat dari biaya yang dikeluarkan selama menjalankan usahatani kopi.

\section{KESIMPULAN}

1. Pendapatan yang didperoleh usahatani kopi di Kecamatan Gangga, Kabupaten Lombok Utara, Nusa Tenggara Barat rata-rata sebesar Rp.12.581.046/Th per usahatani kopi, sementara jika dihitung rata-rata per hektar luas lahan usahatani memperoleh pendapatan sebesar Rp. 7.625.046/Th. Hal ini membuktikan bahwa usahatani kopi di Kecamatan Gangga memperoleh pendapatan yang cukup tinggi dalam pertahunnya.

2. Kelayakan usahatani kopi di Kecamatan Gangga, Kabupaten Lombok Utara, Nusa Tenggara Barat setelah dilakukan analisis R/C Ratio adalah sebesar 3,9 yang membuktikan bahwa $\mathrm{R} / \mathrm{C}>1$ dinyatakan usahatani tersebut layak dijalankan karena total penerimaan yang diperoleh lebih besar daripada total biaya yang dikeluarkan oleh usahatani.

3. Berdasarkan hasil penelitian bahwa usahatani kopi di Kecamatan Gangga, Kabupaten Lombok Utara, Nusa Tenggara Barat memperoleh profitabilitas usaha sebesar 295\%. Hal 
ini membuktikan bahwa usahatani kopi di Kecamatan Gangga, Kabupaten Lombok Utara, Nusa Tenggara Barat sangat efisien untuk dijalankan.

\section{DAFTAR PUSTAKA}

Aak.1980. Budidaya Tanaman Kopi. Yayasan Kanisius, Yogyakarta.

Amisan, 2017 Analisis Pendapatan Usahatani Kopi di Desa Purworejo Timur, Kecamatan Modayag, Kabupaten Bolaang Mongondow Timur. Jurnal Agribisnis. Volume 13 Nomor 2 A: 229-236.

Amir, 2018 Analisis Usahatani Kopi di Kelompok Tani Hutan Giri Senang, Desa Giri Mekar, Kabupaten Bandung. Jurnal Agribisnis. UNPAD Hal. 842-847.

Anonim. 2020. Buku Panduan Penulisan Skripsi Program Sarjana Sosial Ekonomi Pertanian. Institut Pertanian STIPER Yogyakarta. Yogyakarta.

Assauri, Sofyan. 1995. Manajemen Produksi \& Operasi. Jakarta: LBFE UI.

Badan Pusat Statistik Kabupaten Lombok Utara. 2018. Luas Lahan dan Produksi Kopi Dalam Angka Tahun 2018. Lombok Utara.

Brigham, Eugene F dan Joel F. Houston. 2011. Dasar - Dasar Manajemen Keuangan. Edisi 11. Erlangga. Jakarta. Direktorat Jenderal Perkebunan

Kementerian Pertanian. 2018. Perkembangan nilai volume dan ekspor kopi. http://ditjenbun.pertanian.go.id/berita-362-pertumbuhan-nilaiekspor-kopimeningkat.html.

Ferry Dkk. 2015. Budidaya tanaman kopi: Teori dan Aplikasi. Jakarta: PT RajaGrafindo.

Hernanto, F. 1991. Ilmu Usahatani. PT Penebar Swadaya. Jakarta

International Coffee Organization (ICO). 2018. ICO Annual Review. International Coffee Organization. London.

Miller, Roger dan Roger E. Meiners, 2000. Teori Mikro Ekonomi Intermediate, Jakarta: PT Raja Grafindo Pesada.

Panggabean, E. 2011. Buku Pintar Kopi. Agromedia Pustaka: Jakarta.

Prawirokusumo. Soeharto. 2002. IImu Usaha Tani dan ekonomi kerakyatan. BPFE. Yogyakarta.

Rahardjo, P. 2012. Panduan Budidaya dan Pengolahan Kopi Arabika dan Robusta. Penebar Swadaya. Jakarta

Rifkyansyah. 2018. Analisis Pendapatan Usahatani Kopi Arabika di Desa Tanjung Beringin, Kecamatan Sumbul, Kabupaten Dairi. JURNAL MASEPI, Vol.3, No.2.

Sari, 2018 Analisis Keuntuangan dan Efisiensi Penggunaan Biaya Usahatani Kopi Rakyat Robusta di Kecamatan Sumber Wringin, Kabupaten Bondowoso. Jurnal Agribisnis. Volume 02, No 01.

Soekartawi, 1995. Analisis Usahatani. Universitas Indonesia. Jakarta

Soekartawi. 2006. Prinsip Dasar Ekonomi Pertanian: Teori dan Aplikasi. Jakarta: PT RajaGrafindo Persada. 238 hal

Suratiyah. 2006. IImu Usahatani. Penebar Swadaya. Jakarta.

Sutrisno. 2003. Manajemen Keuangan, Teori, Konsep dan Aplikasi. Edisi pertama, Cetakan ketiga. Yogyakarta: Ekonisia. 
Syamsuddin, Lukman. 2000. Manajemen Keuangan Perusahaan: Konsep Aplikasi dalam Perencanaan, Pengawasan, dan Pengambilan Keputusan. PT Raja Grafindo Perkasa, Jakarta.

Yurhaya, 2017. Analisis Profitabilitas Kopi Bubuk Pada Industri Bumi Mutiara Kota Palu. Jurnal Agribisnis. J. Agroland 23 (2): $149-156$ 